\title{
Using Capture-Recapture Methods to Estimate Local Influenza Hospitalization Incidence Rates
}

\section{Authors:}

GK Balasubramani, PhD, ${ }^{1}$ Mary Patricia Nowalk, PhD, RDN,${ }^{2}$ Lloyd G. Clarke, BS

Hons, ${ }^{3}$ Jason A. Lyons, ${ }^{1}$ Klancie Dauer, ${ }^{1}$ Fernanda Silveira, MD, ${ }^{4}$ Donald B. Middleton, MD, ${ }^{5}$ Mohamed Yassin, MD, ${ }^{6}$ Richard K. Zimmerman, MD, MPH, $\mathrm{MA}^{2}$

\section{Affiliations:}

${ }^{1}$ University of Pittsburgh Department of Epidemiology, Suite 600 Schenley Place, 4420 Bayard St., Pittsburgh, PA 15260 USA

${ }^{2}$ University of Pittsburgh Department of Family Medicine, Suite 520 Schenley Place, 4420 Bayard St., Pittsburgh, PA 15260 USA

${ }^{3}$ UPMC Health System Department of Pharmacy, Division of Infectious Diseases/

Pharmacy Department - AMP $5^{\mathrm{TH}}$ Floor Falk Medical Building, 3601 Fifth Ave; Pittsburgh PA USA

${ }^{4}$ University of Pittsburgh Department of Medicine, 3601 Fifth Avenue, Suite 5B, Pittsburgh, PA 15213 USA

${ }^{5}$ Department of Medical Education, UPMC St. Margaret, 815 Freeport Rd., Pittsburgh PA 15215

${ }^{6}$ Infection Control Department UPMC Mercy, 1400 Locust Street Suite 10550 B Building

Pittsburgh, PA, USA 15219

\section{Corresponding author:}

Mary Patricia Nowalk, PhD, RD Department of Family Medicine 4420 Bayard St., Suite 520 Pittsburgh, PA 15260 
tnowalk@pitt.edu

412-383-2355

\section{Word counts:}

Abstract - 266; Text - 2103; Tables - 4; Figures - 1; Supplemental Tables - 4

\section{Funding:}

This work was supported by the Centers for Disease Control and Prevention (CDC) [5U01IP001035-02] and by National Institutes of Health (NIH) [UL1TR001857]. This work represents the views of the authors and not the CDC or NIH. It is subject to CDC's public access policy.

\section{Conflict of Interest:}

Drs. Nowalk and Balasubramani, and Mr. Lyons have grant funding from Merck \& Co., Inc. for an unrelated project. Dr. Zimmerman has grant funding from Sanofi Pasteur and Merck \& Co., Inc. Dr. Silveira has grant funding from Shire, Ansun, Novartis for unrelated projects. Dr. Middleton reports personal fees from Seqirus, grants and personal fees from Pfizer, personal fees from Sanofi Pasteur. Dr. Yassin and Mr. Clarke have no conflicts to report. 


\section{Abstract}

Background: Accurate population estimates of disease incidence and burden are needed to set appropriate public health policy. The capture-recapture (C-R) method combines data from multiple sources to better estimate prevalence than is possible using single sources. This study used the C-R method to estimate influenza cases using research and administrative databases to calculate county-wide influenza hospitalization burden.

Methods: Data were derived from a database of clinical virology test results and research data from an influenza vaccine effectiveness study from seasons 2015-2016 to 2018-2019. Missed influenza cases were estimated using C-R method. These estimates were used to calculate disease burden using the multiplier method to correct for underreporting due to curtailing data collection before the end of influenza circulation.

Results: Over all seasons, 422 influenza cases were reported in the administrative database and 382 influenza cases in the research database. Seventy-five cases (18\%) reported in the administrative database were not captured in the research database, and $35(9 \%)$ cases in the research database were not captured in the administrative database. Completeness of the influenza hospitalization was estimated to be $76 \%$. Influenza hospitalizations were higher among unvaccinated (32\%) than vaccinated $(22 \%)$ in the current season and among unvaccinated (28\%) than vaccinated $(23 \%)$ in the previous year. The incidence rates for influenza hospitalizations varied by age and season and averaged 421 cases/100,000 population annually. 
medRxiv preprint doi: https://doi.org/10.1101/2020.11.03.20225482; this version posted November 5, 2020. The copyright holder for this preprint (which was not certified by peer review) is the author/funder, who has granted medRxiv a license to display the preprint in perpetuity.

All rights reserved. No reuse allowed without permission.

Conclusion: The capture-recapture method offers a more accurate method for estimating influenza hospitalization than relying on a single data source. Using the multiplier method with adjustments improves the detection of influenza disease burden through a matched database. The incidence rates are consistent with national estimates. 


\section{Introduction}

Policy makers and planners need accurate estimates of the incidence or prevalence of diseases and health conditions to anticipate, prevent, and mitigate the effects of those diseases. The decentralized nature of U.S. health care makes overall population burden estimates difficult to calculate. Thus, policy makers must rely on population sampling for estimates, leaving true population burden unknown. The accuracy of population estimates depends largely upon the quality of sampling, which in turn, is dependent upon many factors including constancy of the population being sampled across all capture occasions, ${ }^{1}$ and having contact with the healthcare system to allow for enumeration. Cases of unreported disease are more difficult to count. Estimates of influenza burden for example, may be inaccurate because influenza exhibits a broad spectrum of severity, ranging from cases that do not warrant medical care, but can cause work or school presenteeism or absenteeism, to hospitalization to death.

Statistical methods to improve population disease incidence and prevalence detection include the capture-recapture (C-R) method. C-R uses the overlap of subjects from two or more data sources to more accurately estimate true population burden and can be used to estimate regional or local disease burden. This study used available data from a single health system, C-R calculations, and adjustments for market share and other factors to estimate influenza hospitalization burden in Allegheny County in Western Pennsylvania. 


\section{Methods}

Data

Data used for this analysis were collected from two sources: 1) a local health system's clinical surveillance software system (Theradoc®), which extracts virology test results from the electronic medical record (EMR); and 2) research data from selected hospitals participating in the Hospitalized Adult Influenza Vaccine Effectiveness Network (HAIVEN). The study was approved by the University of Pittsburgh IRB.

An IRB-approved honest broker extracted a data list from Theradoc $®$ of a cohort of Allegheny County residents who received an inpatient clinical respiratory viral panel (RVP) test at two to five (depending upon the season) general acute care hospitals in the health system during the study period that included the 2015-2016 through 20182019 influenza seasons. Specific dates for each season are shown in Supplemental Table 1. This list also contained basic demographic data of race, sex and age and is henceforth called the "administrative" database.

The "research" database was derived from participants who were recruited from the hospitals during the 2015-2016 through 2018-2019 influenza seasons for the HAIVEN study. Detailed study methods for the HAIVEN study have been described elsewhere. ${ }^{2}$ Briefly, patients aged $\geq 18$ years admitted with an acute respiratory infection (ARI) including cough or worsening symptoms of a respiratory illness beginning within 10 days were enrolled. Patients who had been enrolled in the prior 14 days were ineligible. Following informed consent, study staff collected respiratory specimens (nasal and throat swabs from patients) for influenza virus testing (including virus type and subtype) by reverse-transcription polymerase chain reaction (RT-PCR), or used 
results from a RVP test, if available. Demographic data were obtained from interview. Vaccination status was based on documented receipt of each year's influenza vaccine from the Pennsylvania Statewide Immunization Information System (PA-SIIS).

\section{Statistical analyses}

The administrative database was prepared for analysis by limiting it to data from hospitals in which research enrollments were taking place for each influenza season.

For example, in 2015-2016, two hospitals were enrolling participants, whereas in 20182019 there were five participating hospitals. Secondly, data were limited to the periods during which research enrollments were taking place. Thirdly, patients $<18$ years of age were eliminated. Finally, patients were separated into influenza cases and non-cases. Market share data for the UPMC Health System were provided by the Pennsylvania Health Care Cost Containment Council (PHC4).

Summary statistics of the demographic and clinical characteristics were determined for the patients found in both the administrative and research databases (matched database). Number and percent of influenza cases in the databases were calculated and the $\mathrm{C}-\mathrm{R}$ method was used to estimate influenza incidence. ${ }^{3}$

$$
\begin{aligned}
& \text { CR - Population estimate (total influenza) } \\
& =\frac{(\text { Observed administrative cases }(M)) *(\text { Observed research Cases }(n))}{(\text { Observed cases from matched database }(m))}
\end{aligned}
$$

Using the observed rates provides Petersen's estimate of $(\mathrm{N})$ which is,

$$
\widehat{\mathrm{N}}=\frac{(M) *(n)}{m}
$$

This population estimate assumes that the probability of being captured by one source does not affect the probability of being captured by the other source. ${ }^{12}$ Calculation of 
completeness of reporting by the two sources of C-R method is defined in Supplemental Table S2 and one example in Supplemental Table S3. From the above equation (1) with simple algebraic manipulation, we get the estimate for administrative $(\widehat{M})$, research $(\hat{n})$, and matched $(\widehat{\mathrm{m}})$.

$$
\begin{array}{ll}
\operatorname{Administrative}(\widehat{\mathrm{M}}) & =\frac{(N) *(m)}{n} \\
\operatorname{Research}(\hat{\mathrm{n}}) & =\frac{(N) *(m)}{M} \\
\operatorname{Matched} \text { database }(\widehat{\mathrm{m}}) & =\frac{(M) *(n)}{(N)}
\end{array}
$$

The variance and $95 \%$ confidence intervals (Cls) were calculated using the formula defined in (1) which is as follows:

$$
\begin{gathered}
\operatorname{Variance}(\widehat{\mathrm{N}})=\frac{M * n * N_{1} * N_{2}}{m^{3}} \\
95 \% \mathrm{CI}=\widehat{\mathrm{N}} \pm 1.96 * \sqrt{\operatorname{Variance}(\widehat{\mathrm{N}})}
\end{gathered}
$$

$N_{1}$ : Number of cases reported only in administrative database, and $N_{2}$ : Number of cases reported only in research database. These values are not included in the tables.

Population burden estimates were made using the following equations:

$$
\text { Burden estimate }=\frac{\text { Adjusted number of cases from CR estimate }}{\text { Adult population in Allegheny County }}
$$

Adjusted number of cases from CR estimate $=$ Number of cases from CR estimate $*$ $\left(\frac{1}{\text { Proportion of ARI enrolled based on multiplier to ARI }\left(\frac{B}{C}\right)}\right) *\left(\frac{1}{\text { ARI Market share of study hospitals }\left(\frac{C}{D}\right)}\right) *$ $\left(\frac{1}{\text { Proportion of study period influenza detections compared to the year }(E / F)}\right)$ 
To correct for underdetection of influenza hospitalization burden, we adjusted the rate of viral detections for all, for each age group, and other measures listed in Table 1 by the proportion of subjects tested for influenza during the study period and ran sensitivity analyses for the entire year influenza testing. The overall level of detection was summarized using the multiplier method in Equation (2), that is the expected number of true influenza hospitalizations per reported hospitalization in Allegheny County in those seasons. In sensitivity analyses, we estimated influenza cases and disease burden with 95\% confidence intervals for the $2017-2018$ and $2018-2019$ seasons for age groups, race category, sex, season, vaccination status, and prior vaccination status using the same methods. Data were analyzed using SAS version 9.4 (SAS Institute, Cary, NC, USA). 


\section{Results}

The final analytic databases are shown in Figure 1. The administrative database consisted of 8,440 patients, the research database consisted of 1,765 patients and 1,825 patients were matched in both databases. Demographic characteristics of the patients found in the matched database are shown in Table 1. The highest proportion of the group was 50-64 years old (34\%) with the remainder approximately equally divided among patients who were 18-49, 65- 64 and $75+$ years old. The patients in this group were predominantly white $(70 \%)$, female $(63 \%)$ and vaccinated $\geq 14$ days prior to illness onset (58\%). Half of them had been vaccinated in the previous season and $25 \%$ were influenza cases.

Table 2 shows the observed and estimated influenza hospitalizations among persons hospitalized with a cough illness in the administrative, research and matched databases, overall seasons, by season and by other factors. Among hospitalized persons with a cough illness, the observed influenza incidence over all seasons was $25 \%$ ranging from $19.6 \%$ to $34.1 \%$ across the four seasons. Influenza hospitalizations were slightly higher in the 65-74-year age group compared with others and among blacks than whites. Larger differences in influenza hospitalizations were seen between unvaccinated (30.8\%) and vaccinated patients $(21.8 \%)$ and between those vaccinated in the previous year $(27.6 \%)$ and those not previously vaccinated $(22.5 \%)$. The estimated influenza hospitalizations did not differ from observed rates by more than a percentage point or two across all groups.

Table 3 shows the proportion of observed influenza cases captured and estimated influenza cases captured (coverage) overall, and for each of the subgroups. Again, the observed and estimated values were remarkably similar. Notably, the lowest 
proportion captured in both observed and estimated values were among groups from the research database (18-49-year-olds and 2015-2016 influenza season) with the smallest sample sizes $(<400)$.

The estimated influenza incidence values based on C-R method were then used to determine the burden of influenza hospitalization across all health system hospitals in Allegheny County shown in Table 4. Over all four influenza seasons, the average incidence rate for hospitalized influenza was $421 / 100,000$. The lowest rate was $282 / 100,000$ in 2018-2019 and the highest rate was 630/100,000 in 2017-2018, an especially severe influenza season.

In sensitivity analyses, burden estimates were made for two seasons with sufficient numbers by age group shown in Supplemental Table 4. Influenza hospitalization burden was highest in those $\geq 75$ years in both seasons. Burden was considerably higher in the 2017-2018 A/H3N2 dominated season, than in 2018-2019 that was characterized by nearly equal incidence of $\mathrm{A} / \mathrm{H} 1 \mathrm{~N} 1$ and $\mathrm{A} / \mathrm{H} 3 \mathrm{~N} 2$. 


\section{Discussion}

This study used capture-recapture methods to calculate influenza incidence among hospitalized patients using two data sources - an administrative database and a research database. C-R has been adapted from ecological studies and used in a wide array of health-related studies including Alzheimer's disease, heart attack, HIV infection, gun injury, pediatric disease surveillance, gastric cancer, and norovirus infections. ${ }^{4-9}$

Direct C-R uses two databases and is believed to result in better estimates than indirect C-R, which uses three or more databases. In this study, estimates were nearly identical between observed and estimated incidence. By comparison, in a C-R study of norovirus cases, the combined databases yielded incidence at a rate 2.5 times the level of the rate of the highest individual database. ${ }^{9}$ Moreover, in the current study, the overlap between databases was large, resulting in high disease coverage estimates.

This study met three of the four assumptions needed for confidence in the reliability of the outcomes. 1) The populations could be considered closed, that is, there was little chance of loss of cases due to outmigration or death. In a disease of short incubation and duration such as influenza, loss to outmigration is minimal. 2) High overlap of cases improves reliability of estimates because of low missed cases. In this study, there was a large overlap of cases between the databases allowing for matching of pairs of cases (same person, both databases). 3) Databases should be homogeneous. The two databases in this study are believed to be homogeneous, in that cases in both have a nearly equal probability of being identified. 4) The data sources should be independent to prevent over- or underestimation of missing cases. Although they were identified using different methods, the cases in the research database were all hospitalized in the same hospitals from which the administrative 
database was drawn. Thus, independence of the samples was decreased. An additional assumption is that large databases should be normally distributed within loglinear models. The differences observed in proportion captured in the two population subgroups with smaller sample sizes may be a reflection of non-normal distributions.

Because of our confidence in the hospitalization estimates, county-wide incidence rates were calculated. Influenza hospitalization incidence was highest in 2017-2018, an influenza A/H3N2-dominated year and lowest in 2015-2016 an influenza $\mathrm{A} / \mathrm{H} 1 \mathrm{~N} 1$ dominated year. ${ }^{10}$ This finding is not unexpected, given influenza A/H3N2's higher severity than influenza $A / H 1 N 1$. Using $C-R$ methods, influenza hospitalization incidence estimates among children have ranged from 240/100,000 in 2003-2004 ${ }^{12}$ and $860 / 100,000$ in $2004-2005^{13}$ to $89 / 100,000$ for the $2009 \mathrm{~A} / \mathrm{H} 1 \mathrm{~N} 1$ influenza pandemic. ${ }^{14}$ Among adults, during the $2009 \mathrm{~A} / \mathrm{H} 1 \mathrm{~N} 1$ pandemic, influenza related hospitalizations were $178 / 100,000$ for adults $18-49$ years and $76 / 100,000$ for those $\geq 50$ years of age. ${ }^{14}$ Strengths and Limitations

This study is one of only a few capture-recapture papers for influenza hospitalization rates among adults and the only one of which we are aware for these seasons. It has the advantage of also including vaccination status. The results are consistent with national estimates and validate the population burden estimates that Pittsburgh contributes to CDC's HAIVEN study. ${ }^{15}$

Limitations include conducting the study in only one county, although countyspecific population burden is a key outcome. Assumptions on independence of the captures was not made. The sources of the positive or negative dependence may lead to underestimation or over estimation of the population size. However, this difficulty can 
be verified through a modelling process by fitting various models to the data to handle dependence among sources and make adjustments by including interaction terms in the model. ${ }^{11}$ Log-linear models were not conducted because the intent of the paper is to estimate the population size of influenza cases and influenza disease burden. Finally, funding and time constraints limited the duration of active surveillance during the influenza season for the research database.

\section{Conclusions}

Influenza illness is associated with significant costs that include lost productivity due to absenteeism and presenteeism, lost wages, and costs of medical care. Understanding the burden of influenza hospitalization is important for policy makers to allocate resources for the prevention and treatment of influenza. This study validates the influenza population burden estimates that our site contributes to the CDC's HAIVEN study.

\section{Acknowledgement}

The Pennsylvania Health Care Cost Containment Council (PHC4) is an independent state agency responsible for addressing the problem of escalating health costs, ensuring the quality of health care, and increasing access to health care for all citizens regardless of ability to pay. PHC4 has provided data to this entity in an effort to further PHC4's mission of educating the public and containing health care costs in Pennsylvania.

PHC4, its agents, and staff, have made no representation, guarantee, or warranty, express or implied, that the data-financial, patient, payor, and physician 
medRxiv preprint doi: https://doi.org/10.1101/2020.11.03.20225482; this version posted November 5, 2020. The copyright holder for this preprint (which was not certified by peer review) is the author/funder, who has granted medRxiv a license to display the preprint in perpetuity. All rights reserved. No reuse allowed without permission.

specific information-provided to this entity, are error-free, or that the use of the data will avoid differences of opinion or interpretation.

This analysis was not prepared by PHC4. This analysis was done by the University of

Pittsburgh. PHC4, its agents and staff, bear no responsibility or liability for the results of the analysis, which are solely the opinion of this entity. 


\section{References}

1. Hwang $\mathrm{W}-\mathrm{H}$, Huggins R. An examination of the effect of heterogeneity on the estimation of population size using capture-recapture data. . Biometrika. 2005;92(1):229-233.

2. Ferdinands JM, Gaglani M, Martin ET, et al. Prevention of influenza hospitalization among adults in the United States, 2015-2016: results from the US Hospitalized Adult Influenza Vaccine Effectiveness Network (HAIVEN). The Journal of infectious diseases. 2018.

3. Ackman DM, Birkhead G, Flynn M. Assessment of surveillance for meningococcal disease in New York State, 1991. American journal of epidemiology. 1996;144(1):78-82.

4. Waller M, Mishra GD, Dobson AJ. Estimating the prevalence of dementia using multiple linked administrative health records and capture-recapture methodology. Emerging themes in epidemiology. 2017;14(1):3.

5. Razzak JA, Mawani M, Azam I, Robinson C, Talib U, Kadir MM. Burden of out-ofhospital cardiac arrest in Karachi, Pakistan: Estimation through the capturerecapture method. J Pak Med Assoc. 2018;68(7):990-993.

6. Poorolajal J, Mohammadi Y, Farzinara F. Using the capture-recapture method to estimate the human immunodeficiency virus-positive population. Epidemiology and Health. 2017;39.

7. Post LA, Balsen Z, Spano R, Vaca FE. Bolstering gun injury surveillance accuracy using capture-recapture methods. Journal of behavioral medicine. 2019;42(4):674-680. 
8. Knowles RL, Smith A, Lynn R, Rahi JS. Using multiple sources to improve and measure case ascertainment in surveillance studies: 20 years of the British Paediatric Surveillance Unit. Journal of public health. 2006;28(2):157-165.

9. Hardstaff J, Clough H, Harris J, Lowther J, Lees D, O'Brien S. The use of capture-recapture methods to provide better estimates of the burden of norovirus outbreaks from seafood in England, 2004-2011. Epidemiology \& Infection. $2019 ; 147$.

10. Centers for Disease Control and Prevention. National and Regional Level Outpatient Illness and Viral Surveillance.

http://gis.cdc.gov/grasp/fluview/fluportaldashboard.html. Accessed February 17, 2016.

11. Chao A, Tsay P, Lin SH, Shau WY, Chao DY. The applications of capture-recapture models to epidemiological data. Statistics in medicine. $2001 ; 20(20): 3123-3157$.

12. Grijalva CG, Weinberg GA, Bennett NM, Staat MA, Craig AS, Dupont WD, Iwane MK, Postema AS, Schaffner W, Edwards KM, Griffin MR. Estimating the undetected burden of influenza hospitalizations in children. Epidemiol Infect. 2007 Aug;135(6):951-8. doi: 10.1017/S095026880600762X. Epub 2006 Dec 7. PMID: $17156502 ;$ PMCID: PMC2870647.

13. Grijalva CG, Craig AS, Dupont WD, Bridges CB, Schrag SJ, Iwane MK, Schaffner W, Edwards KM, Griffin MR. Estimating influenza hospitalizations among children. Emerg Infect Dis. 2006 Jan;12(1):103-9. doi: 10.3201/eid1201.050308. PMID: 16494725; PMCID: PMC3372368. 
medRxiv preprint doi: https://doi.org/10.1101/2020.11.03.20225482; this version posted November 5, 2020. The copyright holder for this preprint (which was not certified by peer review) is the author/funder, who has granted medRxiv a license to display the preprint in perpetuity.

All rights reserved. No reuse allowed without permission.

14. Jules A, Grijalva CG, Zhu Y, Talbot KH, Williams JV, Dupont WD, Edwards KM, Schaffner W, Shay DK, Griffin MR. Estimating age-specific influenza-related hospitalization rates during the pandemic (H1N1) 2009 in Davidson Co, TN. Influenza Other Respir Viruses. 2012 May;6(3):e63-71. doi: 10.1111/j.1750-2659.2012.00343.x. Epub 2012 Feb 23. PMID: 22360812; PMCID: PMC3773818.

15. Ferdinands JM, Gaglani M, Martin ET, Middleton D, Monto AS, Murthy K, Silveira FP, Talbot HK, Zimmerman R, Alyanak E, Strickland C, Spencer S, Fry AM; HAIVEN Study Investigators. Prevention of Influenza Hospitalization Among Adults in the United States, 2015-2016: Results From the US Hospitalized Adult Influenza Vaccine Effectiveness Network (HAIVEN). J Infect Dis. 2019 Sep 13;220(8):1265-1275. doi:

10.1093/infdis/jiy723. PMID: 30561689; PMCID: PMC6743848. 
Table 1. Demographic characteristics of patients identified in the overlapping database $(\mathrm{N}=1,825)$

\begin{tabular}{|lc|}
\hline Variable & Total \\
& $\mathrm{N}(\%)$ \\
\hline Age group & \\
18-49 years & $357(19.6)$ \\
$50-64$ years & $615(33.7)$ \\
$65-74$ years & $418(22.9)$ \\
$75+$ years & $435(23.8)$ \\
Race & \\
White & $1,274(69.8)$ \\
Black & $502(27.5)$ \\
Other, unknown & $49(2.7)$ \\
Sex & \\
Female & \\
Male & $1,141(62.5)$ \\
Season & $684(37.5)$ \\
$2015-2016$ & $498(27.3)$ \\
$2016-2017$ & $342(18.7)$ \\
Vaccination Status & $422(23.1)$ \\
& \\
\hline & \\
\hline
\end{tabular}


medRxiv preprint doi: https://doi.org/10.1101/2020.11.03.20225482; this version posted November 5, 2020. The copyright holder for this preprint (which was not certified by peer review) is the author/funder, who has granted medRxiv a license to display the preprint in perpetuity. All rights reserved. No reuse allowed without permission.

\section{Unvaccinated}

Vaccinated $\geq 14$ days prior to illness onset

Vaccinated $<14$ days prior to illness onset

Prior year vaccination (total for all seasons)

No

Yes
$623(34.1)$

1,062 (58.2)

$140(7.7)$

905 (49.6)

$920(50.4)$ 
Table 2. Estimated population influenza hospitalizations using the capture-recapture method

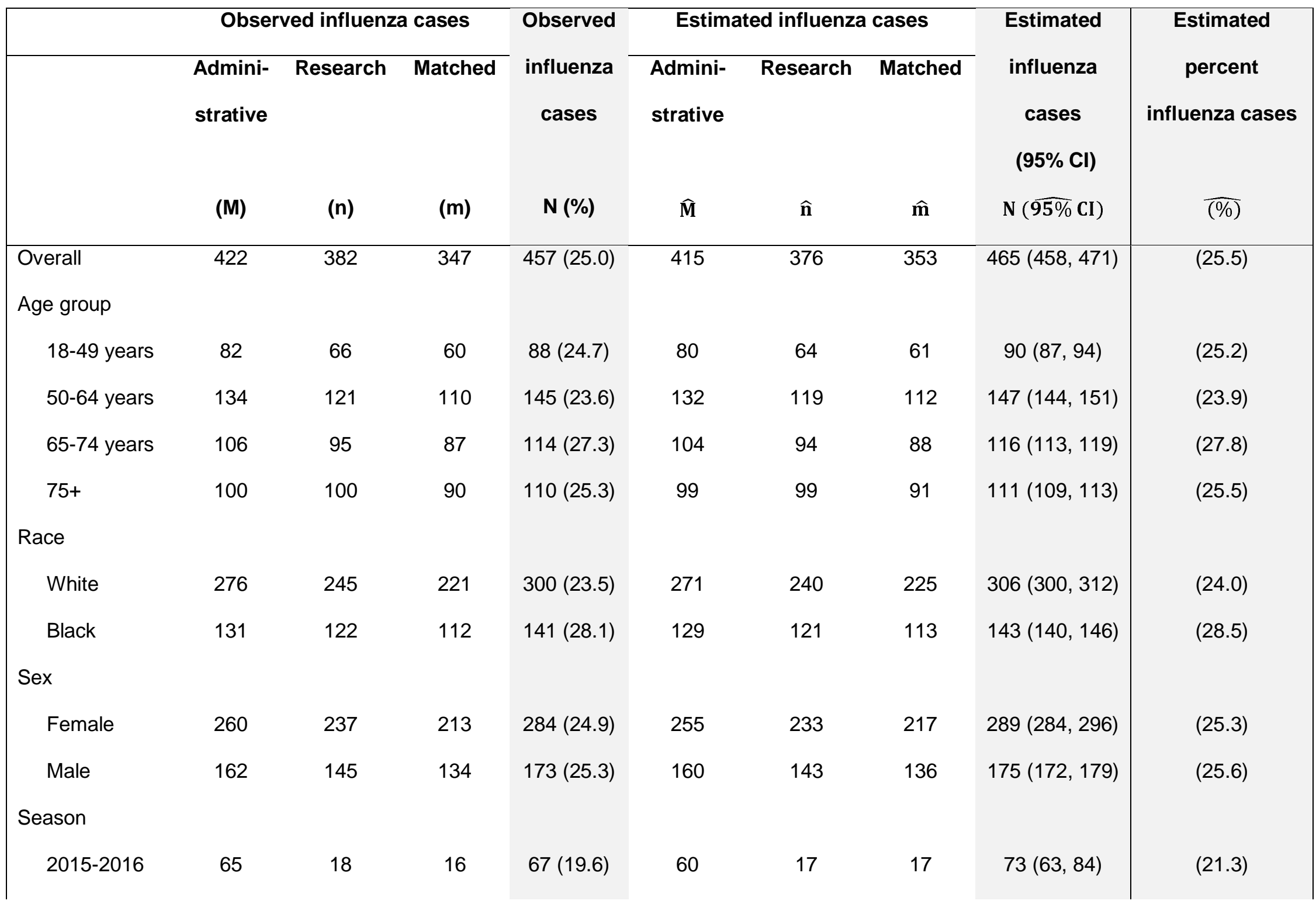




\begin{tabular}{|c|c|c|c|c|c|c|c|c|c|}
\hline 2016-2017 & 102 & 102 & 95 & $109(25.8)$ & 102 & 102 & 95 & $110(108,111)$ & $(26.1)$ \\
\hline 2017-2018 & 157 & 157 & 144 & $170(34.1)$ & 156 & 156 & 145 & $171(169,174)$ & (34.3) \\
\hline 2018-2019 & 98 & 105 & 92 & $111(19.7)$ & 97 & 104 & 93 & $112(110,114)$ & (19.9) \\
\hline \multicolumn{10}{|l|}{ Vaccination Status } \\
\hline Unvaccinated & 177 & 152 & 137 & $192(30.8)$ & 173 & 149 & 140 & $196(192,201)$ & (31.5) \\
\hline Vaccinated & 213 & 204 & 186 & $231(21.8)$ & 211 & 202 & 188 & $234(230,237)$ & (22.0) \\
\hline \multicolumn{10}{|l|}{ Prior vaccination } \\
\hline No & 234 & 205 & 189 & $250(27.6)$ & 231 & 202 & 192 & $254(249,258)$ & $(28.1)$ \\
\hline Yes & 188 & 177 & 158 & 207 (22.5) & 185 & 174 & 161 & $211(206,214)$ & (22.9) \\
\hline
\end{tabular}


Table 3. Observed and estimated proportion of cases captured, using the capture-recapture method

\begin{tabular}{|c|c|c|c|c|c|c|}
\hline & \multicolumn{3}{|c|}{ Observed proportion of cases captured (\%) } & \multicolumn{3}{|c|}{ Estimated proportion of cases captured (\%) } \\
\hline & Administrative & Research & Matched & Administrative & Research & Matched \\
\hline $\begin{array}{l}\text { Over all } 4 \text { seasons } \\
2015-2019 \\
\text { Age group }\end{array}$ & 92.3 & 83.6 & 75.9 & 89.2 & 80.9 & 75.9 \\
\hline $18-49$ years & 93.2 & 75.0 & 68.2 & 88.9 & 71.1 & 67.8 \\
\hline $50-64$ years & 92.4 & 83.4 & 75.9 & 89.8 & 81.0 & 76.2 \\
\hline $65-74$ years & 93.0 & 83.3 & 76.3 & 89.7 & 81.0 & 75.9 \\
\hline $75+$ & 90.9 & 90.9 & 81.8 & 89.2 & 89.2 & 82.0 \\
\hline \multicolumn{7}{|l|}{ Race } \\
\hline White & 92.0 & 81.7 & 73.7 & 88.6 & 78.4 & 73.5 \\
\hline Black & 92.9 & 86.5 & 79.4 & 90.2 & 84.6 & 79.0 \\
\hline \multicolumn{7}{|l|}{ Sex } \\
\hline Female & 91.5 & 83.5 & 75.0 & 88.2 & 80.6 & 75.1 \\
\hline
\end{tabular}




\begin{tabular}{|c|c|c|c|c|c|c|}
\hline Male & 93.6 & 83.8 & 77.5 & 91.4 & 81.7 & 77.7 \\
\hline \multicolumn{7}{|l|}{ Season } \\
\hline $2015-2016$ & 97.0 & 26.9 & 23.9 & 82.2 & 23.3 & 23.3 \\
\hline 2016-2017 & 93.6 & 93.6 & 87.2 & 92.7 & 92.7 & 86.4 \\
\hline $2017-2018$ & 92.4 & 92.4 & 84.7 & 91.2 & 91.2 & 84.8 \\
\hline 2018-2019 & 88.3 & 94.6 & 82.9 & 86.6 & 92.9 & 83.0 \\
\hline \multicolumn{7}{|c|}{ Vaccination Status } \\
\hline Unvaccinated & 92.3 & 99.2 & 71.4 & 88.3 & 76.0 & 71.4 \\
\hline Vaccinated & 92.2 & 88.3 & 80.5 & 90.2 & 86.3 & 80.3 \\
\hline \multicolumn{7}{|l|}{ Prior vaccination } \\
\hline No & 93.6 & 82.0 & 75.6 & 90.0 & 79.5 & 75.6 \\
\hline Yes & 90.8 & 85.5 & 76.3 & 87.7 & 82.5 & 76.3 \\
\hline
\end{tabular}


Table 4. Influenza hospitalization incidence rates per 100,000 Allegheny County population

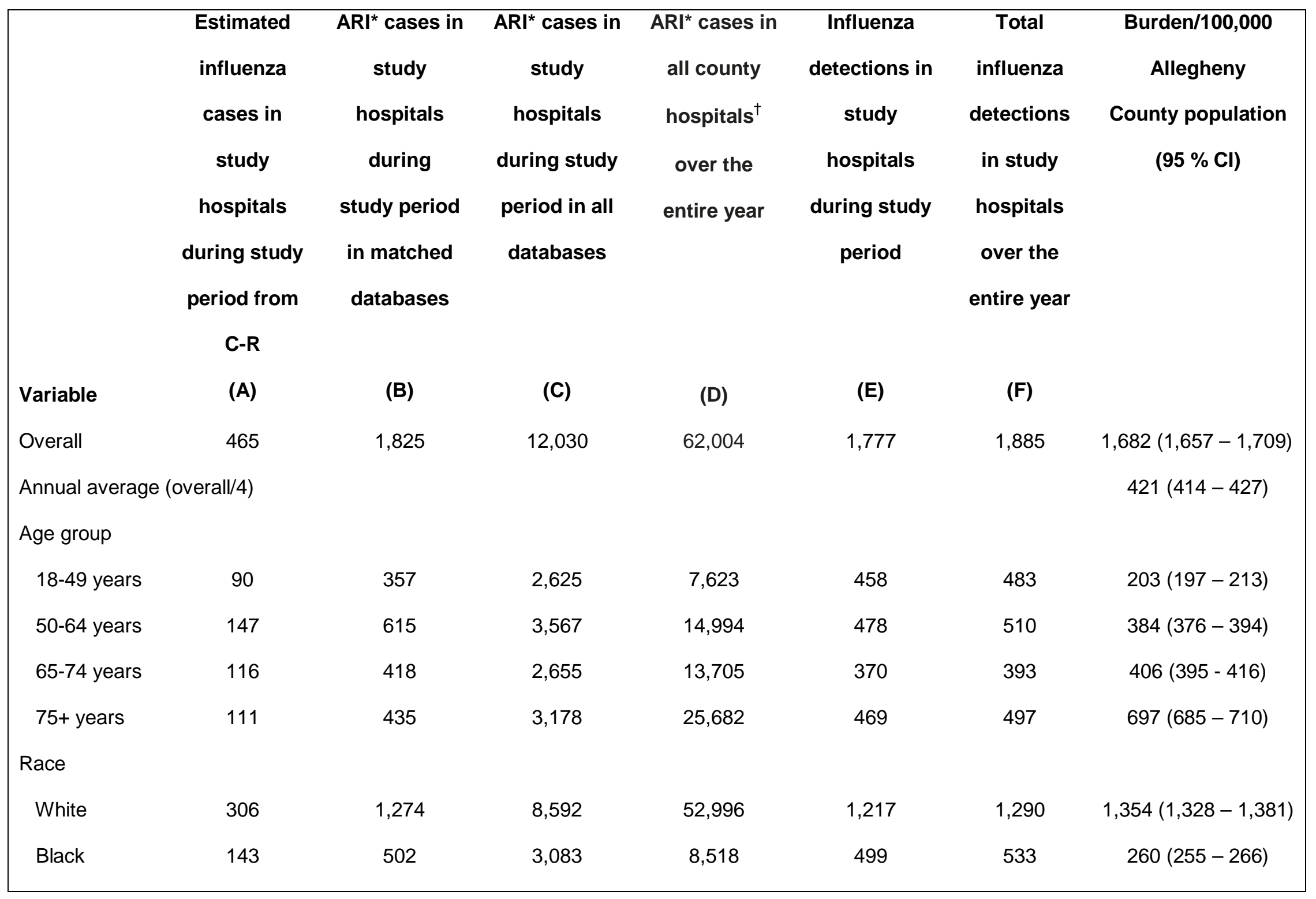




\begin{tabular}{|lccccccc|}
\hline Season & & & & & & & \\
$2015-2016$ & 73 & 342 & 1,284 & 15,554 & 164 & $364(314-419)$ \\
$2016-2017$ & 110 & 422 & 2,229 & 16,171 & 377 & 386 & $433(425-437)$ \\
$2017-2018$ & 171 & 498 & 3,378 & 16,353 & 642 & 718 & $630(623-641)$ \\
$2018-2019$ & 112 & 563 & 5,139 & 13,926 & 594 & 602 & $282(277-287)$ \\
& & & & & & & \\
\end{tabular}

${ }^{\dagger}$ All health system hospitals in Allegheny County 


\section{Supplemental Tables}

Table S1. HAIVEN enrollment period dates

\begin{tabular}{|ll|}
\hline Season $2015-2016$ & $12 / 14 / 2015$ to $4 / 28 / 2016$ \\
Season 2016 2017 & $11 / 14 / 2016$ to $4 / 27 / 2017$ \\
Season 2017-2018 & $10 / 31 / 2017$ to $3 / 28 / 2018$ \\
Season 2018-2019 & $11 / 01 / 2018$ to $4 / 30 / 2019$ \\
\hline
\end{tabular}

Table S2. Calculation of completeness of reporting by the two independent sources Capture-Recapture method

\begin{tabular}{|l|c|c|c|}
\hline \multirow{2}{*}{ Research database } & \multicolumn{2}{|c|}{ Administrative Database } & \multirow{2}{*}{ Total } \\
\cline { 2 - 3 } & Cases with clinical test & Cases missed & $n$ \\
\hline Cases enrolled & $m$ & $N_{2}$ & \\
\hline Cases missed & $N_{1}$ & $X$ & $\widehat{N}$ \\
\hline Total & $M$ & & \\
\hline
\end{tabular}

$m=$ number of cases identified by both data sources; $N_{2}$ : Number of cases reported only in research database; $n$ is the number of cases identified in research database source; $N_{1}$ : Number of cases reported only in administrative database; $X$ is the number cases not reported in either databases. It is estimated from both database $X=\left(N_{1} * N_{2}\right) / m$; $M$ is the number cases identified in administrative database source; and $\widehat{N}$ is the estimated total number of cases and is defined in equation (1).

Table S3. Example of Capture-Recapture estimate

\begin{tabular}{|c|c|c|c|}
\hline \multirow[b]{2}{*}{ Research database } & \multicolumn{2}{|c|}{ Administrative Database } & \multirow[b]{2}{*}{ Total } \\
\hline & $\begin{array}{c}\text { Cases } \\
\text { Clinical Test }\end{array}$ & $\begin{array}{c}\text { Cases } \\
\text { Missed }\end{array}$ & \\
\hline Cases Enrolled & $347(m)$ & $35\left(N_{2}\right)$ & $382(n)$ \\
\hline Cases Missed & $75\left(N_{1}\right)$ & $8(X)$ & \\
\hline Total & $422(M)$ & & $465(\mathbb{N})$ \\
\hline
\end{tabular}

$\widehat{N}=465(95 \% C I 458,471)$ 
Table S4. Burden estimates by age group for seasons 2017-2018 and 2018-2019 per 100,000 persons

\begin{tabular}{|c|c|c|c|c|c|c|c|}
\hline Variable & $\begin{array}{l}\text { Estimated } \\
\text { Influenza cases } \\
\text { in study } \\
\text { hospitals } \\
\text { during study } \\
\text { period based } \\
\text { on CR method } \\
\text { (A) }\end{array}$ & $\begin{array}{l}\text { ARI }^{*} \text { cases in } \\
\text { study } \\
\text { hospitals } \\
\text { during study } \\
\text { period in } \\
\text { matched } \\
\text { databases } \\
\text { (B) }\end{array}$ & $\begin{array}{l}\text { ARI }^{*} \text { cases in } \\
\text { study } \\
\text { hospitals } \\
\text { during study } \\
\text { period in all } \\
\text { databases } \\
\text { (C) }\end{array}$ & $\begin{array}{l}\text { ARI }^{\star} \text { cases } \\
\text { in all } \\
\text { county } \\
\text { hospitals } \\
\text { over the } \\
\text { entire year } \\
\text { (D) }\end{array}$ & $\begin{array}{l}\text { Influenza } \\
\text { detections in } \\
\text { study } \\
\text { hospitals } \\
\text { during study } \\
\text { period } \\
\text { (E) }\end{array}$ & $\begin{array}{l}\text { Total } \\
\text { influenza } \\
\text { detections } \\
\text { in study } \\
\text { hospitals } \\
\text { over the } \\
\text { entire year } \\
\text { (F) }\end{array}$ & $\begin{array}{l}\text { Burden/ } \\
100,000 \\
\text { Allegheny } \\
\text { County } \\
\text { population } \\
(95 \% \mathrm{Cl})\end{array}$ \\
\hline $\begin{array}{l}\text { 2017-2018 season } \\
\text { Age group }\end{array}$ & 171 & 498 & 3,378 & 16,353 & 642 & 718 & $630(623-641)$ \\
\hline $18-49$ years & 29 & 95 & 717 & 1,955 & 149 & 164 & $66(64-68)$ \\
\hline $50-64$ years & 48 & 157 & 952 & 3,838 & 153 & 179 & $138(135-144)$ \\
\hline $65-74$ years & 44 & 124 & 761 & 3,644 & 128 & 141 & $143(140-146)$ \\
\hline $75+$ years & 49 & 122 & 945 & 6,916 & 210 & 232 & $308(302-321)$ \\
\hline $\begin{array}{l}\text { 2018-2019 season } \\
\text { Age group }\end{array}$ & 112 & 563 & 5,139 & 13,926 & 594 & 602 & $282(277-287)$ \\
\hline $18-49$ years & 20 & 116 & 1,086 & 1,725 & 172 & 174 & $30(29-32)$ \\
\hline $50-64$ years & 43 & 207 & 1,540 & 3,360 & 188 & 191 & $71(70-73)$ \\
\hline $65-74$ years & 27 & 129 & 1,143 & 3,299 & 124 & 126 & $70(68-73)$ \\
\hline $75+$ years & 21 & 111 & 1,369 & 5,542 & 110 & 111 & $106(101-111)$ \\
\hline
\end{tabular}


medRxiv preprint doi: https://doi.org/10.1101/2020.11.03.20225482; this version posted November 5, 2020. The copyright holder for this preprint (which was not certified by peer review) is the author/funder, who has granted medRxiv a license to display the preprint in perpetuity.

All rights reserved. No reuse allowed without permission.

\section{Figure 1}

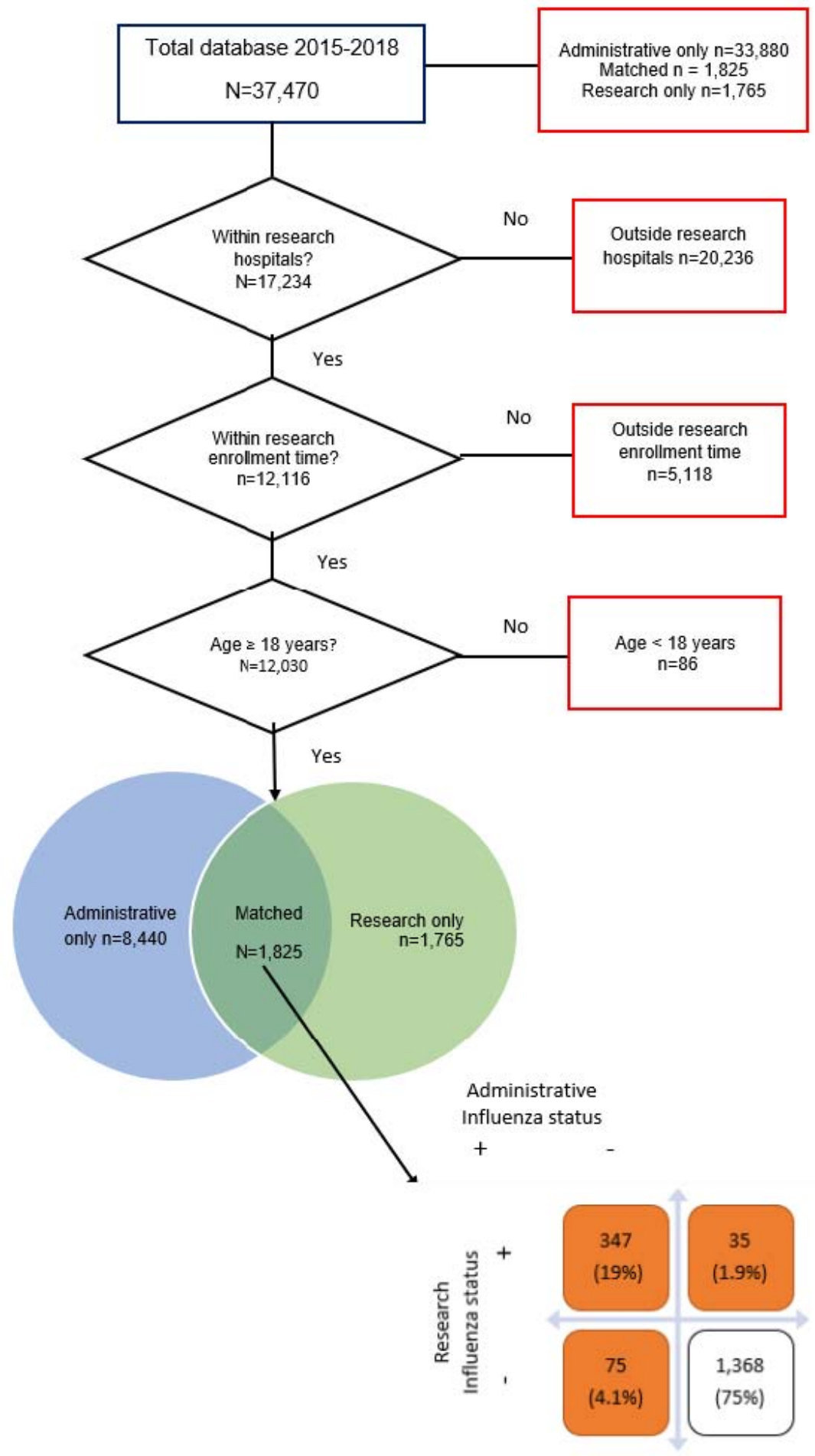


medRxiv preprint doi: https://doi.org/10.1101/2020.11.03.20225482; this version posted November 5, 2020. The copyright holder for this preprint (which was not certified by peer review) is the author/funder, who has granted medRxiv a license to display the preprint in perpetuity.

All rights reserved. No reuse allowed without permission.

Figure 1 Legend. Flow Chart Capture - Recapture Method of Estimating Population Size 